\title{
Pengaruh Jenis Residu Kompos Biochar dan Umur Defoliasi Daun Jagung (Zea mays L.) terhadap Pertumbuhan dan Hasil Kacang Merah (Phaseulus vulgaris L.) dalam Tumpangsari Salome
}

\author{
Krisantus Tri Pambudi Raharjo ${ }^{\mathrm{a}}$ dan Venidora R. Delang ${ }^{\mathrm{b}}$ \\ ${ }^{a}$ Fakultas Pertanian, Universitas Timor, Kefamenanu, TTU - NTT, Indonesia, email: initriraharjaa@gmail.com \\ ${ }^{b}$ Fakultas Pertanian, Universitas Timor, Kefamenanu,TTU - NTT, Indonesia, email: delangveni@gmail.com
}

\section{Article Info}

Article history:

Received 22 Juni 2020

Received in revised form 11 Juli 2020

Accepted 23 Juli 2020

DOI:

https://doi.org/10.32938/sc.v5i03.1054

Keywords:

Umur Defoliasi

Kacang Merah

Residu Kompos

Tumpang sari Salome

\section{Abstrak}

Penelitian ini bertujuan untuk mengetahui pengaruh residu jenis kompos biochar pada musim tanaman kedua dan pengaruh perlakuan umur defoliasi daun jagung terhadap pertumbuhan dan hasil tanaman kacang merah dengan tumpangsari salome tanaman jagung. Penelitian telah dilaksanakan pada bulan Juli sampai dengan November 2019 di kebun percobaan Fakultas Pertanian, Universitas Timor, Kelurahan Sasi, Kecamatan Kota Kefamenanu, Kabupaten Timor Tengah Utara (TTU), Provinsi Nusa Tenggara Timur (NTT). Penelitian ini menggunakan Rancangan Acak Kelompok (RAK) Faktorial 3 x 3 yang diulang sebanyak 3 kali. Faktor Pertama adalah jenis residu biochar yang terdiri dari 3 aras yaitu residu kompos biochar pupuk kandang sapi, residu kompos biochar pupuk kandang kambing, residu kompos biochar pupuk kandang Kuda. Faktor kedua adalah waktu defoliasi daun jagung yang terdiri dari 3 aras yaitu tanpa defoliasi, defoliasi pada umur 35 HST, defoliasi pada umur 55 HST, sehingga terdapat 9 kombinasi perlakuan, yang diulang sebanyak 3 kali sehingga terdapat 27 satuan percobaan. Hasil Penelitian menunjukan terjadi pengaruh positif menurut uji DMRT taraf $5 \%$ antara kombinasi perlakuan jenis residu kompos biochar dan perlakuan umur defoliasi daun jagung terhadap suhu tanah 60 HST, berat volume tanah 60 HST, dan berat kering tajuk. Faktor tunggal perlakuan jenis residu kompos biochar yang diperkaya pupuk kandang kambing mampu memodifikasi lingkungan tumbuh tanaman dan meningkatkan pertumbuhan serta hasil tanaman. Faktor tunggal perlakuan umur defoliasi daun jagung 35 HST mampu meningkatkan pertumbuhan dan hasil tanaman kacang merah.

\section{Pendahuluan}

Tumpangsari merupakan penanaman dua atau lebih tanaman yang ditanam secara serentak pada lahan yang sama setiap tahun. Keuntungan sistem tumpangsari yaitu mengurangi resiko gagal panen, memperbaiki kesuburan, mengurangi terjadinya erosi dan meningkatkan pendapatan petani (Sukoco et al., 1992). Dalam pertanian organic terdapat dua keuntungan yaitu adanya tanaman pada sistem tumpangsari dapat menekan gulma sehingga mengurangi tindakan pengendalian gulma dan adanya fiksasi N2 oleh tanaman tumpangsari. Sistem tumpangsari, salah satu upaya untuk meningkatkan hasil tanaman dan sekaligus memaksimalkan pemanfaatan lahan, karena terdapat dua atau lebih jenis tanaman yang berbeda yang ditanam secara bersamaan dalam waktu relatif sama. Salah satu bentuk kearifan lokal yang dimiliki masyarakat pulau Timor adalah sistem pertanaman, dengan menanam beberapa jenis tanaman pangan yang berbeda spesies secara bersamaan waktu dalam lubang tanam yang sama (Salome) (Levis et al., 2017). Sistem salome (satu lobang ramairamai) merupakan sistem tumpangsari spesifik wilayah karena hanya dilakukan di wilayah Timor Barat. Sistem ini cukup efektif untuk mengantisipasi perubahan iklim dan serangan hama penyakit yang menyebabkan gagal panen. Petani percaya bahwa dengan sistem salome mampu meningkatkan standar ketahanan pangan keluarga.

Provinsi NTT dan daerah lain di kawasan Indonesia Timur, khususnya masyarakat di daerah TTU cukup banyak membudidayakan kacang merah secara monokultur. Kacang merah (Phaseulus vulgaris L.) merupakan salah satu jenis kacang sayur yang dapat dimanfaatkan sebagai bahan pangan. Teknik budidaya kacang merah juga sama dengan kedelai maupun kacang hijau dan dapat ditanam pada dataran menengah sampai dataran tinggi. Tanaman ini biasanya ditanam secara monokultur. Budidaya kacang merah di Kabupaten TTU secara monokultur yang diterapkan oleh petani tidak terlalu efektif dikarenakan cara budidaya masih dilakukan secara tradisional diantaranya tidak menggunakan pupuk dasar dan tidak menggunakan sistem ekonomis antara tanaman kacang merah dengan tanaman lain.

Produksi kacang merah dapat membantu meningkatkan kualitas gizi masyarakat karena dapat dijadikan sebagai sumber protein nabati yang murah. Kacang merah memiliki komponen penyusun utama yaitu pati dan protein. Kandungan pati dalam kacang merah sebesar 39,45 \% dapat menjadi sumber energi bagi tubuh dan kandungan protein sebesar $24 \%$ yang bermanfaat pada regenerasi sel-sel dalam tubuh yang rusak (Buttdan Batool, 2010). Menurut Nurfi (2009), Kacang merah juga memiliki komponen serat yang cukup tinggi yaitu sekitar 4 g per $100 \mathrm{~g}$ kacang merah kering. Kandungan serat dalam kacang merah tersebut dapat melancarkan pencernaan. Di Indonesia kacang merah telah banyak dibudidayakan di berbagai daerah seperti Jawa Barat hingga TTU. Hasil uji daya genotip AZ-7 pada Kacang merah di Bedali, Malang pada ketinggian tempat 450 mdpl mampu berproduksi 1.36 ton ha-1 dan pada ketinggian 800 mdpl yaitu 1,50 ton ha-1 (Adie dan Agung, 2002). Kacang merah mempunyai peluang dikembangkan di Indonesia dan dapat ditanam secara tumpangsari karena mempunyai jumlah bintil dan kemampuan memfiksasi nitrogen cukup baik.

Produksi kacang merah di TTU sendiri selalu mengalami fluktuasi dari tahun ke tahun. Badan Pusat Statistik (BPS) TTU (2011) produksi kacang merah di TTU pada tahun 2008 adalah 135 ton sementara pada tahun 2009 menurun menjadi 40 ton dan tahun 2010 menjadi 30 ton. Hal ini disebabkan oleh beberapa hal seperti perubahan iklim yang tidak menentu dan juga anggapan masyarakat bahwa kacang merah hanya dapat dibudidayakan di dataran tinggi. Untuk menunjang pertumbuhan tanaman kacang merah maka perlu diterapkan teknologi yang dapat memperbaiki tekstur dan juga struktur tanah yang ada di dataran menengah, teknologi yang dapat diterapkan adalah pemanfaatan penggunaan residu pupuk organik dan juga biochar diduga akan sangat membantu menunjang pertumbuhan kacang merah. Naben dalam Tas'au (2018) membuktikan dalam penelitiannya bahwa tanaman kacang merah di dataran menengah yang diberikan pupuk guano dengan takaran 10 ton ha ${ }^{-1}$ memperoleh bobot biji per petak sebesar 1,17 tonha $^{-1}$. Dengan presentasi peningkatan hasil sebesar $31,1 \%$ yang berbeda nyata dengan pemberian guano 5 tonha $^{-1}$ dan kontrol. Demikian pula pemberian biochar menunjukkan tidak berbeda nyata walaupun level biochar terus ditingkatkan level pemberiannya, tetapi mampu meningkatkan hasil tanaman.

Kompos biochar merupakan salah satu jenis pupuk organik yang dalam pembuatannya menggunakan campuran bahan-bahan organik seperti kotoran ternak dan hijauan dengan biochar sebagai bahan pembenah tanah. Dengan demikian biochar tidak langsung diaplikasikan ke tanah melainkan biochar digunakan sebagai bahan pencampur (bulking agent) dalam pembuatan kompos sebelum diberikan ke dalam tanah salah satu fungsi biochar sebagai bulking agent dalam proses pengomposan adalah memperbaiki proses humifikasi dan kualitas akhir kompos (Lehmandan Rondon., 2006). Penggunaan bahan organik seperti pupuk kandang di dalam tanah selain dapat meninggalkan efek residu di dalam tanah. Menurut Setyamidjaja (1986), pupuk organik terutama pupuk kandang sapi dipakai sehingga meningkatkan sifat-sifat fisik, kimia dan biologi tanah. Penggunaan bahan organik tidak hanya menambah ketersediaan hara bagi tanaman, tetapi juga menciptakan kondisi yang sesuai bagi tanaman dengan memperbaiki aerasi, mempermudah penetrasi akar, dan memperbaiki kapasitas menahan air (BOA, 2008). Efek residu dari pupuk organik dapat menjadi cadangan unsur hara sehingga dapat dimanfatkan untuk penanaman pada periode berikutnya (Yulia dan Murniati, 2010). Selanjutnya Islami (2012), residu pupuk kandang 15 tonha $^{-1}$ menghasilkan berat biji jagung sebanyak 5,24 tonha ${ }^{-1}$ yang berbeda sangat nyata dengan pemberian pupuk kandang 15 tonha $^{-1}$ yang hanya menghasilkan berat biji jagung sebanyak 3,78 tonha $^{-1}$

Defoliasi adalah pemotongan atau pengambilan bagian tanaman yang ada di atas permukaan tanah. Defoliasi daun pada tanaman jagung dengan tujuan untuk mengurangi persaingan cahaya sehingga tidak mempengaruhi proses fotosintesis pada tanaman yang ditumpangsarikan. Dalam mengurangi saling menaungi antar tanaman maupun antar daun dalam tanaman pada saat proses fotosintesis perlu adanya penjarang tanaman ataupun penjarangan daun tanaman. Defoliasi juga dapat meningkatkan penumpukan hasil fotosintesis pada biji tanaman. Faktor yang perlu diperhatikan dalam melakukan defoliasi adalah umur tanaman, interval dan tinggi defoliasi. Perlakuan defoliasi tergantung dari kecepatan tumbuh tanaman. Waktu defoliasi yang singkat akan mempengaruhi "regrowth" dari tanaman dan waktu defoliasi yang lama dapat menyebabkan peningkatkan pada bobot batang tanaman (Setyati, 1979). Model pemangkasan daun jagung tidak berpengaruh terhadap berat biji kacang merah Hal ini sesuai dengan pernyataan Permanasari dan Kastono (2012) bahwa pertumbuhan kedelai tidak berpengaruh terhadap pemangkasan jagung. Hopkins (1995), defoliasi adalah pemangkasan ujung batang. Selanjutnya Herman (2002), menyatakan bahwa defoliasi semua daun di bawah klobot jagung akan mengurangi kemampuan tanaman dalam berfotosintesis sehingga bisa menurunkan produksi.

Hasil dari defoliasi daun bisa dimanfaatkan untuk keperluan pakan ternak. Dari uraian tersebut maka saya melakukan penelitian mengenai "Pengaruh Jenis Residu Kompos Biochar dan Umur Defoliasi Daun Jagung terhadap Pertumbuhan dan Hasil Tanaman Kacang Merah dalam Tumpangsari Salome" yang bertujuan untuk untuk mengetahui pengaruh residu jenis kompos 
biochar pada musim tanaman kedua dan untuk mengetahui pengaruh perlakuan umur defoliasi daun jagung terhadap pertumbuhan dan hasil tanaman kacang merah dengan tumpangsari tanaman jagung.

\section{Metode}

Penelitian ini dilaksanakan pada bulan Juli sampai dengan November 2019 di kebun percobaan Fakultas Pertanian, Universitas Timor, Kelurahan Sasi, Kecamatan Kota Kefamenanu, Kabupaten Timor Tengah Utara (TTU) Provinsi Nusa Tenggara Timur (NTT). Pada topografi berbukit dan ketinggian $450 \mathrm{mdpl}$, suhu udara berkisar $32-34{ }^{\circ} \mathrm{C}$ dan $\mathrm{pH}$ tanah berkisar $6,0-6,5$ Penelitian ini menggunakan Rancangan Acak Kelompok (RAK) Faktorial 3 × 3 yang diulang sebanyak 3 kali. Faktor pertama adalah jenis residu biochar (B) yang terdiri dari 3 aras yaitu residu kompos biochar pupuk kandang sapi $\left(B_{1}\right)$, residu kompos biochar pupuk kandang kambing $\left(\mathrm{B}_{2}\right)$, residu kompos biochar pupuk kandang kuda $\left(\mathrm{B}_{3}\right)$. Faktor kedua adalah waktu defoliasi daun jagung $(\mathrm{P})$ yang terdiri dari 3 aras yaitu tanpa defoliasi $\left(\mathrm{P}_{0}\right)$, defoliasi pada umur 35 HST $\left(\mathrm{P}_{1}\right)$, defoliasi pada umur 55 HST $\left(\mathrm{P}_{2}\right)$, sehingga terdapat 9 kombinasi perlakuan yaitu: $\mathrm{B}_{1} \mathrm{P}_{0}, \mathrm{~B}_{1} \mathrm{P}_{1}, \mathrm{~B}_{1} \mathrm{P}_{2}, \mathrm{~B}_{2} \mathrm{P}_{0}, \mathrm{~B}_{2} \mathrm{P}_{1}, \mathrm{~B}_{2} \mathrm{P}_{2}, \mathrm{~B}_{3} \mathrm{P}_{0}, \mathrm{~B}_{3} \mathrm{P}_{1}, \mathrm{~B}_{3} \mathrm{P}_{2}$, yang diulang sebanyak 3 kali sehingga terdapat 27 satuan percobaan. Selain itu dilakukan pula penanaman kacang maupun jagung secara monokultur.

Penelitian ini menggunakan lahan penelitian sebelum tanpa merubah apapun didalam lahan kecuali pembersihan gulma sebelum penanaman dan pemeliharan lainnya. Parameter pengamatan dalam penelitian ini adalah Suhu Tanah, Kadar Lengas Tanah, Berat Volume Tanah, Tinggi Tanaman Jumlah Daun, Luas Daun, Jumlah polong pertanaman, Berat biji per tanaman, Berat biji per petak, Berat 100 biji, Berat Biji Per Hektar, Berat kering berangkasan, Indeks panen. Data hasil pengamatan kemudian dianalisis dengan menggunakan analisis sidik ragam (Anova) dengan Rancangan Acak Kelompok (RAK). Rata-rata perlakuan selanjutnya diuji lanjut dengan menggunakan Duncan Multiple Range Test (DMRT) dengan tingkat signifikan $(0,05 \%)$ sesuai petunjuk Gomez dan Gomez (2010). Analisis data menggunakan program SAS.

\section{Hasil dan Pembahasan}

\subsection{Hasil}

\section{Suhu Tanah $\left({ }^{0} \mathrm{C}\right)$}

Hasil sidik ragam anova menunjukkan tidak terjadi interaksi antara perlakuan residu kompos biochar diperkaya jenis pupuk kandang dengan perlakuan umur defoliasi daun jagung terhadap suhu tanah awal pengamatan tetapi pada saat tanaman berumur 60 HST terjadi interaksi. Hasil uji lanjut DMRT terhadap suhu tanah -1 HST menunjukkan aras perlakuan residu kompos biochar yang perkaya pupuk kandang kuda mampu menekan peningkatan suhu tanah dan berbeda nyata dengan aras perlakuan lainnya sedangkan aras perlakuan umur defoliasi menunjukkan tidak ada pengaruh nyata antara aras perlakuan. Kombinasi perlakuan residu kompos biochar diperkaya jenis pupuk kandang dengan perlakuan umur defoliasi tanaman jagung 55 HST pada musim tanam kedua mampu menekan peningkatan suhu tanah (Tabel 1.). Penurunan suhu tanah disebabkan akibat residu bahan organik yang terkandung dalam tanah mampu mengikat air sehingga permukaan tanah menjadi lebih dingin dan daun jagung mampu menutup permukaan tanah sehingga cahaya matahari tidak menembus pada permukaan tanah secara langsung serta kandungan aerase tanah mampu mempertahan peningkatan suhu tanah. Hal ini dikatakan dalam penelitian Tambunan (2014), bahan organik berperan untuk menjaga kelembapan tanah, penyangga hara tanaman, membantu dalam meningkatkan penyediaan hara.

Table 1. Suhu Tanah $\left({ }^{\circ} \mathrm{C}\right)$

\begin{tabular}{|c|c|c|c|c|c|}
\hline \multirow{2}{*}{$\begin{array}{l}\text { Waktu } \\
\text { Pengamatar } \\
\text { (HST) }\end{array}$} & \multirow{2}{*}{$\begin{array}{c}\text { Jenis Residu Kompos } \\
\text { Biochar }\end{array}$} & \multicolumn{3}{|c|}{ Umur Defoliasi (HST) } & \multirow[b]{2}{*}{ Rerata } \\
\hline & & Kontrol & 35 & 55 & \\
\hline \multirow{4}{*}{$-1 \mathrm{HST}$} & Pupuk Kandang Sapi & 30,61 & 32,76 & 29,34 & $30,90 \mathrm{a}$ \\
\hline & $\begin{array}{l}\text { PupukKandang } \\
\text { Kambing }\end{array}$ & 31,92 & 31,07 & 28,90 & $30,63 \mathrm{a}$ \\
\hline & Pupuk Kandang Kuda & 29,18 & 26,28 & 28,06 & $27,84 \mathrm{~b}$ \\
\hline & Rerata & $30,57 \mathrm{a}$ & $30,04 \mathrm{a}$ & $28,77 \mathrm{a}$ & $(-)$ \\
\hline \multirow{4}{*}{$60 \mathrm{HST}$} & Pupuk Kandang Sapi & $32,67 a b c$ & $32,41 a b c$ & $33,19 a b c$ & c 32,76 \\
\hline & $\begin{array}{l}\text { Pupuk Kandang } \\
\text { Kambing }\end{array}$ & 31 , & 37,13 a & 4 bc & 33,70 \\
\hline & Pupuk Kandang Kuda & $35,50 \mathrm{ab}$ & $30,89 \mathrm{bc}$ & $30,35 \mathrm{c}$ & 32,25 \\
\hline & Rerata & 33,35 & 33,48 & 31,86 & $(+)$ \\
\hline
\end{tabular}

Keterangan: Angka pada baris dan kolom yang sama diikuti huruf sama menunjukkan tidak berbeda pada tingkat nyata ( $\alpha$ ) $5 \%$ menurut uji DMRT.(-) tidak terjadi interaksi antar faktor. (+): Terjadi interaksi antar faktor.

\section{Kadar Lengas Tanah (\%)}

Hasil sidik ragam anova menunjukkan tidak terjadi interaksi antara perlakuan residu kompos biochar yang diperkaya jenis pupuk kandang dengan umur defoliasi tanaman jagung terhadap kadar lengas tanah. Hasil Uji lanjut DMRT terhadap residu kompos biochar yang diperkaya jenis pupuk kandang maupun perlakuan umur defoliasi daun jagung menunjukkan data tidak ada beda nyata antara perlakuan pada setiap waktu pengamatan (Tabel 2). Dari data tabel terlihat lengas tanah pada setiap waktu pengamatan menunjukkan peningkatan pada waktu pengamatan awal dan menurun pada akhir pengamatan, hal ini disebabkan akibat dari faktor lingkungan, namun residu bahan organik dan umur defoliasi daun jagung mampu memperbaiki airase tanah.

\begin{tabular}{|c|c|c|c|c|c|}
\hline \multirow{2}{*}{$\begin{array}{c}\text { Waktu } \\
\text { Pengamatan } \\
\text { (HST) } \\
\end{array}$} & \multirow{2}{*}{$\begin{array}{c}\text { Jenis Residu } \\
\text { Kompos Biochar }\end{array}$} & \multicolumn{3}{|c|}{ Umur Defoliasi (HST) } & \multirow[b]{2}{*}{ Rerata } \\
\hline & & kontrol & 35 & 55 & \\
\hline \multirow{4}{*}{$-1 \mathrm{HST}$} & Pupuk Kandang Sapi & 31,42 & 30,87 & 30,98 & $\overline{31,09 \mathrm{a}}$ \\
\hline & $\begin{array}{l}\text { Pupuk Kandang } \\
\text { Kambing }\end{array}$ & 31,52 & 33,56 & 33,56 & 32,08 a \\
\hline & $\begin{array}{c}\text { Pupuk Kandang } \\
\text { Kuda } \\
\end{array}$ & 31,26 & 31,25 & 31,15 & $31,22 \mathrm{a}$ \\
\hline & Rerata & $31,40 \mathrm{a}$ & $31,89 \mathrm{a}$ & 31,90 & $(-)$ \\
\hline \multirow{4}{*}{$60 \mathrm{HST}$} & Pupuk Kandang Sapi & 24,30 & 23,34 & 22,62 & $23,42 \mathrm{a}$ \\
\hline & $\begin{array}{c}\text { Pupuk Kandang } \\
\text { Kambing }\end{array}$ & 20,21 & 24,84 & 24,64 & $23,23 \mathrm{a}$ \\
\hline & $\begin{array}{c}\text { Pupuk Kandang } \\
\text { Kuda }\end{array}$ & 31,26 & 22,81 & 25,34 & 26,47 a \\
\hline & Rerata & $25,25 \mathrm{a}$ & $23,66 \mathrm{a}$ & $24,20 \mathrm{a}$ & $(-)$ \\
\hline
\end{tabular}

Keterangan: Angka pada baris dan kolom yang sama diikuti huruf sama menunjukkan tidak berbeda pada tingkat nyata ( $\alpha$ ) $5 \%$ menurut uji DMRT.(-) tidak terjadi interaksi antar faktor.

\section{Berat Volume Tanah $\left(\mathrm{g} / \mathrm{cm}^{2}\right)$}

Hasil sidik ragam anova menunjukkan tidak terjadi interaksi antara perlakuan residu kompos biochar diperkaya jenis pupuk kandang dengan perlakuan umur defoliasi daun jagung terhadap berat volume tanah sedangkan umur 60 HST terjadi interaksi. Residu kompos biochar diperkaya pupuk kandang kuda maupun perlakuan umur defoliasi daun jagung menunjukkan tidak ada pengaruh nyata antara aras perlakuan pada umur -1 HST. Kombinasi perlakuan residu kompos biochar diperkaya jenis pupuk kandang sapi dengan perlakuan umur defoliasi tanaman 55 hst mampu menurunkan volume tanah menjadi lebih baik (Tabel3). Pengamatan menunjukkan residu bahan organik mampu memperbaiki dan mempertahankan sifat fisik tanah.

\section{Tabel 3. Berat Volue Tanah $\left(\mathrm{g} / \mathrm{cm}^{2}\right)$}

\begin{tabular}{|c|c|c|c|c|c|}
\hline \multirow{2}{*}{$\begin{array}{c}\text { Waktu } \\
\text { Pengamatan } \\
\text { (HST) }\end{array}$} & \multirow{2}{*}{$\begin{array}{c}\text { Jenis Residu Kompos } \\
\text { Biochar }\end{array}$} & \multicolumn{3}{|c|}{ Umur Defoliasi (HST) } & \multirow[b]{2}{*}{ Rerata } \\
\hline & & Kontrol & 35 & 55 & \\
\hline \multirow{4}{*}{$-1 \mathrm{HST}$} & Pupuk Kandang Sapi & 1,55 & 1,60 & 1,59 & $1,58 \mathrm{a}$ \\
\hline & Pupuk Kandang Kambing & 1,55 & 1,63 & 1,73 & $1,64 \mathrm{a}$ \\
\hline & Pupuk Kandang Kuda & 1,45 & 1,58 & 1,56 & $1,53 \mathrm{a}$ \\
\hline & Rerata & $1,52 \mathrm{a}$ & $1,60 \mathrm{a}$ & $1,63 a$ & $(-)$ \\
\hline \multirow{4}{*}{$60 \mathrm{HST}$} & Pupuk Kandang Sapi & $1,59 \mathrm{ab}$ & $1,71 \mathrm{a}$ & $1,38 \mathrm{c}$ & 1,56 \\
\hline & Pupuk Kandang Kambing & $1,63 \mathrm{ab}$ & $1,42 \mathrm{bc}$ & $1,45 \mathrm{bc}$ & 1,50 \\
\hline & Pupuk Kandang Kuda & $1,67 \mathrm{a}$ & $1,44 \mathrm{bc}$ & $1,57 \mathrm{abc}$ & 1,56 \\
\hline & Rerata & 1,63 & 1,52 & 1,47 & $(+)$ \\
\hline
\end{tabular}

Keterangan: Angka pada baris dan kolom yang sama diikuti huruf sama menunjukkan tidak berbeda pada tingkat nyata (a) $5 \%$ menurut uji DMRT.(-) tidak terjadi interaksi antar faktor. (+): Terjadi interaksi antar faktor.

\section{Tinggi Tanaman (cm)}

Hasil sidik ragam anova menunjukkan tidak terjadi interaksi antara perlakuan residu kompos biochar yang diperkaya jenis pupuk kandang dengan perlakuan umur defoliasi daun jagung terhadap tinggi tanaman pada setiap waktu pengamatan. Perlakuan residu kompos biochar yang diperkaya jenis pupuk kandang menunjukkan data tidak ada beda nyata antara perlakuan pada setiap waktu pengamatan. Aras perlakuan umur defolisi tanaman jagung 55 HST menunjukkan data tinggi tanaman tertinggi dan berbeda nyata dengan aras perlakuan lainnya pada setiap waktu pengamatan (Tabel 4.). Residu bahan organik dan perlakuan umur defoliasi daun jagung berpengaruh meningkatkan pertumbuhan pada setiap waktu pengamatan. Hal ini dikatakan bahwa residu bahan organik pada musim tanam kedua mampu menyediakan unsur hara dalam peningkatan tanaman.

\section{Jumlah Daun (helai)}

Hasil sidik ragam anova menunjukkan tidak terjadi interaksi antara perlakuan residu kompos biochar yang diperkaya jenis pupuk kandang dengan perlakuan umur defoliasi daun jagung terhadap jumlah daun pada setiap waktu pengamatan. Perlakuan residu kompos biochar yang diperkaya jenis pupuk kandang dan perlakuan umur defolisi daun jagung menunjukkan data tidak ada beda nyata antara perlakuan pada waktu pengamatan 15 HST, 30 HST, dan 45 HST. Pada waktu pengamatan 60 HST tidak terjadi interaksi antara perlakuan (Tabel 5). Perlakuan residu kompos biochar diperkaya jenis pupuk kandang kuda menunjukkan jumlah daun tanaman paling banyak dan berbeda nyata antara aras perlakuan. Perlakuan umur defolisi tanaman jagung menunjukkan data jumlah daun tanaman tidak ada pengaruh nyata antara perlakuan. Residu dari bahan organik dan umur defoliasi jagung berpengaruh dalam pembentukan 
jumlah daun tanaman hal ini disebabkan oleh kandungan unsur hara dan sifat dari tanaman kacang yang menyukai tempat yang memiliki naungan tetapi tetap saya butuh cahaya matahari untuk proses kehidupan tanaman.

Tabel 4. Tinggi Tanaman $(\mathrm{cm})$

\begin{tabular}{|c|c|c|c|c|c|}
\hline \multirow{2}{*}{$\begin{array}{c}\text { Waktu } \\
\text { Pengamatan } \\
\text { (HST) }\end{array}$} & \multirow{2}{*}{$\begin{array}{l}\text { Jenis Residu Kompos } \\
\text { Biochar }\end{array}$} & \multicolumn{3}{|c|}{ Umur Defoliasi (HST) } & \multirow[b]{2}{*}{ Rerata } \\
\hline & & Kontrol & 35 & 55 & \\
\hline \multirow{4}{*}{$15 \mathrm{HST}$} & Pupuk Kandang Sapi & 15.88 & 15.89 & 17.09 & $16.29 \mathrm{a}$ \\
\hline & $\begin{array}{c}\text { Pupuk Kandang } \\
\text { Kambing }\end{array}$ & 14.49 & 17.44 & 17.40 & $16.44 \mathrm{a}$ \\
\hline & $\begin{array}{c}\text { Pupuk Kandang } \\
\text { Kuda }\end{array}$ & 17.83 & 16.44 & 18.41 & $17.56 \mathrm{a}$ \\
\hline & Rerata & $16.07 \mathrm{a}$ & $16.59 \mathrm{a}$ & $17.63 \mathrm{a}$ & $(-)$ \\
\hline \multirow{4}{*}{$30 \mathrm{HST}$} & Pupuk Kandang Sapi & 19.32 & 20.23 & 24.82 & $21.46 \mathrm{a}$ \\
\hline & $\begin{array}{l}\text { Pupuk kandang } \\
\text { kambing }\end{array}$ & 17.89 & 23.70 & 22.39 & $21.33 \mathrm{a}$ \\
\hline & Pupuk kandang kuda & 21.81 & 20.96 & 25.31 & $22.69 \mathrm{a}$ \\
\hline & Rerata & $19.67 \mathrm{~b}$ & $21.63 \mathrm{ab}$ & $24.17 \mathrm{a}$ & $(-)$ \\
\hline \multirow{4}{*}{$45 \mathrm{HST}$} & Pupuk Kandang Sapi & 23.56 & 26.12 & 27.79 & $25.82 \mathrm{a}$ \\
\hline & $\begin{array}{c}\text { Pupuk Kandang } \\
\text { Kambing }\end{array}$ & 24.10 & 25.34 & 26.04 & $25.16 \mathrm{a}$ \\
\hline & $\begin{array}{c}\text { Pupuk Kandang } \\
\text { Kuda }\end{array}$ & 22.27 & 26.07 & 29.23 & $25.86 \mathrm{a}$ \\
\hline & Rerata & $23.31 \mathrm{~b}$ & $25.84 \mathrm{ab}$ & $27.69 \mathrm{a}$ & $(-)$ \\
\hline \multirow{4}{*}{$60 \mathrm{HST}$} & Pupuk Kandang Sapi & 25.34 & 27.48 & 30.78 & $27.87 \mathrm{a}$ \\
\hline & $\begin{array}{c}\text { Pupuk Kandang } \\
\text { Kambing }\end{array}$ & 25.68 & 28.78 & 27.54 & $27.33 \mathrm{a}$ \\
\hline & $\begin{array}{c}\text { Pupuk Kandang } \\
\text { Kuda }\end{array}$ & 24.58 & 27.58 & 30.38 & $27.51 \mathrm{a}$ \\
\hline & Rerata & $25.20 \mathrm{~b}$ & $27.94 \mathrm{ab}$ & $29.57 \mathrm{a}$ & $(-)$ \\
\hline
\end{tabular}

Keterangan: Angka pada baris dan kolom yang sama diikuti huruf sama menunjukkan tidak berbeda pada tingkat nyata ( $\alpha$ ) $5 \%$ menurut uji DMRT.(-) tidak terjadi interaksi antar faktor.

Tabel 5. Jumlah Daun (helai).

\begin{tabular}{|c|c|c|c|c|c|}
\hline \multirow{2}{*}{$\begin{array}{c}\text { Waktu } \\
\text { Pengamatan } \\
\text { (HST) }\end{array}$} & \multirow{2}{*}{$\begin{array}{c}\text { Jenis Residu Kompos } \\
\text { Biochar }\end{array}$} & \multicolumn{3}{|c|}{ Umur Defoliasi (HST) } & \multirow[b]{2}{*}{ Rerata } \\
\hline & & Kontrol & 35 & 55 & \\
\hline \multirow{4}{*}{$15 \mathrm{HST}$} & Pupuk Kandang Sapi & 3.33 & 4.00 & 3.33 & $3.56 \mathrm{a}$ \\
\hline & Pupuk Kandang Kambing & 3.67 & 4.00 & 3.00 & $3.56 \mathrm{a}$ \\
\hline & Pupuk Kandang Kuda & 3.67 & 3.33 & 3.67 & $3.56 \mathrm{a}$ \\
\hline & Rerata & $3.56 \mathrm{a}$ & $3.78 \mathrm{a}$ & $3.33 \mathrm{a}$ & $(-)$ \\
\hline \multirow{4}{*}{$30 \mathrm{HST}$} & Pupuk Kandang Sapi & 8.00 & 9.00 & 9.78 & $8.93 \mathrm{a}$ \\
\hline & Pupuk Kandang Kambing & 8.44 & 10.33 & 8.78 & $9.19 \mathrm{a}$ \\
\hline & Pupuk Kandang Kuda & 9.00 & 9.44 & 9.89 & $9.44 \mathrm{a}$ \\
\hline & Rerata & $8.48 \mathrm{a}$ & $9.59 \mathrm{a}$ & $9.48 \mathrm{a}$ & $(-)$ \\
\hline \multirow{4}{*}{45 HST } & Pupuk Kandang Sapi & 11.89 & 12.33 & 14.78 & $13.00 \mathrm{a}$ \\
\hline & Pupuk Kandang Kambing & 12.89 & 15.11 & 12.19 & $13.40 \mathrm{a}$ \\
\hline & Pupuk Kandang Kuda & 13.89 & 17.00 & 18.44 & $16.44 \mathrm{a}$ \\
\hline & Rerata & $12.89 \mathrm{a}$ & $14.81 \mathrm{a}$ & $15.14 \mathrm{a}$ & $(-)$ \\
\hline \multirow{4}{*}{$60 \mathrm{HST}$} & Pupuk Kandang Sapi & 14.00 & 14.56 & 17.78 & $15.44 \mathrm{~b}$ \\
\hline & Pupuk Kandang Kambing & 14.89 & 18.67 & 15.11 & $16.22 \mathrm{ab}$ \\
\hline & Pupuk Kandang Kuda & 16.44 & 19.89 & 21.73 & $19.36 \mathrm{a}$ \\
\hline & Rerata & $15.11 \mathrm{a}$ & $17.70 \mathrm{a}$ & $18.21 \mathrm{a}$ & $(-)$ \\
\hline
\end{tabular}

Keterangan: Angka pada baris dan kolom yang sama diikuti huruf sama menunjukkan

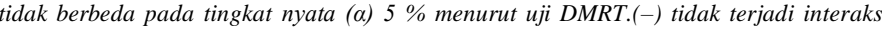
antar faktor.

\section{Luas Daun $\left(\mathrm{cm}^{2}\right)$}

Hasil sidik ragam anova menunjukkan tidak terjadi interaksi antara perlakuan residu kompos biochar yang diperkaya jenis pupuk kandang dengan perlakuan umur defoliasi tanaman jagung pada pengamatan luas daun. Perlakuan residu kompos biochar yang diperkaya jenis pupuk kandang dan perlakuan umur defoliasi tanaman jagung menunjukkan data luas daun tanaman tidak ada beda nyata antara aras perlakuan (Tabel 6.). bila dilihat dari data dalam tabel luas daun tanaman tertinggi dihasilkan pada perlakuan residu bahan organik dan tanpa defoliasi daun jagung, pelebaran daun tanaman dengan tujuan untuk menyerap sinar matahari dalam pembentukan hasil asimilat atau proses fotosintesis.

\section{Jumlah Polong Per Tanaman}

Hasil sidik ragam anova menunjukkan data, tidak terjadi interaksi antara perlakuan residu kompos biochar yang diperkaya jenis pupuk kandang dan perlakuan umur defoliasi daun jagung pada pengamatan jumlah polong per tanaman. Perlakuan kompos biochar yang diperkaya jenis pupuk kandang menunjukkan data tidak ada beda nyata antara perlakuan. Aras perlakuan umur defoliasi daun jagung 55 HST menunjukkan data jumlah polong paling banyak dan berbeda nyata antara aras perlakuan (Tabel 7.). Hal ini dikaji dari manfaat bahan organik mampu menciptakan ruang tumbuh bagi tanaman dan menyediakan unsur hara bagi tanaman sehingga tanaman mampu meningkatkan hasil tanaman yang diekspresikan dengan jumlah polong tanaman terbanyak.

Tabel 6. Luas Daun $\left(\mathrm{cm}^{2}\right)$

\begin{tabular}{ccccc}
\hline Jenis Residu Kompos & \multicolumn{3}{c}{ Umur Defoliasi (HST) } & \multirow{2}{*}{ Rerata } \\
\cline { 2 - 4 } Biochar & Kontrol & 35 & 55 & \\
\hline Pupuk Kandang Sapi & 92,35 & 49,91 & 27,32 & $56,53 \mathrm{a}$ \\
Pupuk Kandang & 53,15 & 77,03 & 76,90 & $69,03 \mathrm{a}$ \\
Kambing & & 29,29 & 49,41 & $62,59 \mathrm{a}$ \\
\hline Pupuk Kandang Kuda & 109,09 & $52,07 \mathrm{a}$ & $51,21 \mathrm{a}$ & $(-)$ \\
\hline Rerata & $84,86 \mathrm{a}$ &
\end{tabular}

Keterangan: Angka pada baris dan kolom yang sama diikuti huruf sama menunjukkan tidak berbeda pada tingkat nyata ( $\alpha$ ) 5\% menurut uji DMRT.(-) tidak terjadi interaksi antar faktor.

Tabel 7. Jumlah Polong Per Tanaman

\begin{tabular}{ccccc} 
Jenis Residu Kompos & \multicolumn{3}{c}{ Umur Defoliasi (HST) } & \multirow{2}{*}{ Rerata } \\
\cline { 2 - 4 } Biochar & Kontrol & 35 & 55 & \\
\hline Pupuk Kandang Sapi & 6,00 & 5,00 & 6,22 & $5,74 \mathrm{a}$ \\
Pupuk Kandang Kambing & 4,89 & 6,00 & 6,11 & $5,67 \mathrm{a}$ \\
Pupuk Kandang Kuda & 4,56 & 5,56 & 6,67 & $5,59 \mathrm{a}$ \\
\hline Rerata & $5,15 \mathrm{~b}$ & $5,52 \mathrm{ab}$ & $6,33 \mathrm{a}$ & $(-)$ \\
\hline
\end{tabular}

Keterangan: Angka pada baris dan kolom yang sama diikuti huruf sama menunjukkan tidak berbeda pada tingkat nyata (a) $5 \%$ menurut uji DMRT.(-) tidak terjadi interaksi antar faktor.

\section{Berat Biji Per Tanaman (g)}

Hasil sidik ragam anova menunjukkan data tidak terjadi interaksi antara perlakuan residu kompos biochar yang diperkaya jenis pupuk kandang dan perlakuan umur defoliasi daun jagung pada pengamatan berat biji per tanaman. Perlakuan kompos biochar yang diperkaya jenis pupuk kandang dan perlakuan umur defoliasi daun jagung menunjukkan data tidak ada beda nyata antara aras perlakuan (Tabel 8.). Peningkatan hasil tanaman yang diekpresikan dengan berat biji terberat dipengaruhi oleh pembentukan hasil asimilat dan dimanfaatkan oleh tanaman dalam penumpukan pada biji tanaman sehingga menghasilkan berat biji perpetak tertinggi.

Tabel 8. Berat Biji Per Tanaman (g)

\begin{tabular}{ccccc}
\hline Jenis Residu Kompos & \multicolumn{3}{c}{ Umur Defoliasi (HST) } & Rerata \\
\cline { 2 - 5 } Biochar & Kontrol & 35 & 55 & \\
\hline Pupuk Kandang Sapi & 5,11 & 4,75 & 4,35 & $4,74 \mathrm{a}$ \\
Pupuk Kandang Kambing & 5,34 & 6,07 & 5,58 & $5,67 \mathrm{a}$ \\
Pupuk Kandang Kuda & 3,88 & 4,86 & 5,19 & $4,64 \mathrm{a}$ \\
\hline Rerata & $4,78 \mathrm{a}$ & $5,23 \mathrm{a}$ & $5,04 \mathrm{a}$ & $(-)$ \\
\hline
\end{tabular}

Keterangan: Angka pada baris dan kolom yang sama diikuti huruf sama menunjukkan tidak berbeda pada tingkat nyata (a) $5 \%$ menurut uji DMRT.(-) tidak terjadi interaksi antar faktor.

\section{Berat Biji Per Petak (g)}

Hasil sidik ragam anova menunjukkan data tidak terjadi interaksi antara perlakuan residu kompos biochar yang diperkaya jenis pupuk kandang dan perlakuan umur defoliasi daun jagung pada pengamatan berat biji per petak Perlakuan kompos biochar yang diperkaya jenis pupuk kandang dan perlakuan umur defoliasi daun jagung menunjukkan data tidak ada beda nyata antara aras perlakuan. Bila dibandingkan pada hasil musim tanam pertama hasilnya meningkat dibandingkan pada musim tanam kedua. Perlakuan kompos biochar diperkaya pupuk kandang kambing menghasilkan berat biji per petak tertinggi pada musim tanam pertama maupun kedua. Faktor tunggal perlakuan tanpa pemangkasan daun jagung meningkatkan hasil diawal penanaman sedangkan pada musim tanam kedua dihasilkan oleh perlakuan defoliasi daun jagung 35 HST (Tabel 9). Penurunan hasil berat biji perpetak pada musim tanam kedua disebabkan karena pupuk kompos yang diaplikasikan pada awal penanaman lebih dimanfaatkan oleh tanaman untuk meningkatkan hasil tanaman, sehingga pada musim penanaman selanjutnya menyebabkan penurun hasil, walaupun demikian residu dari bahan organik masih memberikan efek yang nyata pada musim tanam selanjutnya bila ditinjau dari bahan organik yang bersifat slow release atau melepaskan unsur hara secara bertahap.

Tabel 9. Berat Biji Per Petak pada musim tanam kedua

\begin{tabular}{|c|c|c|c|c|}
\hline \multirow{2}{*}{ Jenis Residu Kompos Biochar } & \multicolumn{3}{|c|}{ Umur Defoliasi (HST) } & \multirow[t]{2}{*}{ Rerata } \\
\hline & Kontrol & 35 & 55 & \\
\hline Pupuk Kandang Sapi & 13,24 & 12,19 & 10,46 & $11,96 \mathrm{a}$ \\
\hline Pupuk Kandang Kambing & 13,09 & 16,82 & 14,58 & $14,83 \mathrm{a}$ \\
\hline Pupuk Kandang Kuda & 9,63 & 13,32 & 10,19 & $11,05 \mathrm{a}$ \\
\hline Rerata & $11,99 \mathrm{a}$ & $14,11 \mathrm{a}$ & $11,74 \mathrm{a}$ & $(-)$ \\
\hline
\end{tabular}

Keterangan: Angka pada baris dan kolom yang sama diikuti huruf sama menunjukkan tidak berbeda pada tingkat nyata ( $\alpha$ ) $5 \%$ menurut uji DMRT.(-) tidak terjadi interaksi antar faktor.

\section{Berat 100 Biji (g)}

Hasil sidik ragam anova menunjukkan data, tidak terjadi interaksi antara perlakuan residu kompos biochar yang diperkaya jenis pupuk kandang 
dan perlakuan umur defoliasi daun jagung pada pengamatan berat 100 biji. Perlakuan kompos biochar yang diperkaya jenis pupuk kandang dan perlakuan umur defoliasi daun jagung menunjukkan data tidak ada beda nyata antara aras perlakuan (Tabel 10.). Residu dari bahan organik yang sifatnya slow release menyediakan unsur hara bagi tanaman pada musim tanaman kedua sehingga mampu meningkatkan berat 100 biji tanaman. Sedangkan defoliasi daun jagung dapat meningkatkan hasil tanaman karena tanaman mampu menyerap unsur hara secara langsung sehingga mampu meproduksi hasil asimilat lebih banyak yang mampu meningkatkan hasil tanaman.

Tabel 10. Berat 100 Biji (g)

\begin{tabular}{ccccc}
\hline \multirow{2}{*}{ Jenis Residu Kompos Biochar } & \multicolumn{3}{c}{ Umur Defoliasi (HST) } & \multirow{2}{*}{ Rerata } \\
\cline { 2 - 4 } & Kontrol & 35 & 55 & \\
\hline Pupuk Kandang Sapi & 28,99 & 26,97 & 26,96 & $27,64 \mathrm{a}$ \\
Pupuk Kandang Kambing & 29,47 & 28,25 & 30,02 & $29,25 \mathrm{a}$ \\
Pupuk Kandang Kuda & 27,36 & 29,21 & 28,18 & $28,25 \mathrm{a}$ \\
\hline Rerata & $28,61 \mathrm{a}$ & $28,15 \mathrm{a}$ & $28,39 \mathrm{a}$ & $(-)$ \\
\hline
\end{tabular}

Keterangan: Angka pada baris dan kolom yang sama diikuti huruf sama menunjukkan tidak berbeda pada tingkat nyata (a) $5 \%$ menurut uji DMRT.(-) tidak terjadi interaksi antar faktor.

\section{Berat Biji Per ha (t/ha)}

Hasil sidik ragam anova menunjukkan tidak terjadi interaksi antara perlakuan residu kompos biochar yang diperkaya jenis pupuk kandang dan perlakuan umur defoliasi daun jagung pada pengamatan berat biji per ha. Perlakuan kompos biochar yang diperkaya jenis pupuk kandang dan perlakuan umur defoliasi daun jagung menunjukkan data tidak ada beda nyata antara aras perlakuan (Tabel 11.). Walaupun dalam faktor lingkungan dan pertumbuhan tidak efektif namun residu bahan organik pupuk kandang kambing berpengaruh besar dalam peningkatkan berat panen biji per hektar hal ini diakibatkan karena unsur hara yang diserap oleh tanaman lebih dimanfaatkan untuk meningkatkan hasil panen. Sedangkan pada umur defoliasi daun jagung lebih efektif dalam penyerapan cahaya matahari sehingga mampu meningkatkan produksi asimilat dan dimanfaatkan oleh tanaman dalam meningkatkan produksi tanaman.

Tabel 11. Berat Biji Per Ha (t/ha)

\begin{tabular}{ccccc}
\hline \multirow{2}{*}{ Jenis Residu Kompos Biochar } & \multicolumn{3}{c}{ Umur Defoliasi (HST) } & Rerata \\
\cline { 2 - 5 } & Kontrol & 35 & 55 & \\
\hline Pupuk Kandang Sapi & 0.034 & 0.031 & 0.027 & $0.031 \mathrm{a}$ \\
Pupuk Kandang Kambing & 0.033 & 0.043 & 0.037 & $0.038 \mathrm{a}$ \\
Pupuk Kandang Kuda & 0.025 & 0.034 & 0.026 & $0.028 \mathrm{a}$ \\
\hline Rerata & $0.031 \mathrm{a}$ & $0.036 \mathrm{a}$ & $0.030 \mathrm{a}$ & $(-)$
\end{tabular}

Keterangan: Angka pada baris dan kolom yang sama diikuti huruf sama menunjukkan tidak berbeda pada tingkat nyata ( $\alpha$ ) $5 \%$ menurut uji DMRT.(-) tidak terjadi interaksi antar faktor.

\section{Berat Kering Berangkasan (g)}

Hasil sidik ragam anova menunjukkan data, tidak terjadi interaksi antara perlakuan residu kompos biochar yang diperkaya jenis pupuk kandang dan perlakuan umur defoliasi daun jagung pada pengamatan berat kering berangkasan. Perlakuan kompos biochar yang diperkaya jenis pupuk kandang dan perlakuan umur defoliasi daun jagung menunjukkan data tidak ada beda nyata antara aras perlakuan (Tabel 12.). Residu bahan organik yang berasal dari pupuk kandang kambing menghasilkan biomasa tanaman tertinggi karena unsur hara yang terkandung dalam bahan organik lebih difokuskan dalam pembentukan hasil asimilat sehingga mampu meningkatkan biomasa tanaman maupun hasil tanaman.

$\underline{\text { Tabel 12. Berat Kering Berangkasan (g) }}$

\begin{tabular}{ccccc}
\hline \multirow{2}{*}{ Jenis Residu Kompos Biochar } & \multicolumn{2}{c}{ Umur Defoliasi (HST) } & \multirow{2}{*}{ Rerata } \\
\cline { 2 - 4 } & Kontrol & 35 & 55 & \\
\hline Pupuk Kandang Sapi & 3.26 & 4.22 & 3.53 & $3.67 \mathrm{a}$ \\
Pupuk Kandang Kambing & 3.88 & 3.14 & 3.18 & $3.40 \mathrm{a}$ \\
Pupuk Kandang Kuda & 3.43 & 3.11 & 4.05 & $3.53 \mathrm{a}$ \\
\hline Rerata & $3.52 \mathrm{a}$ & $3.49 \mathrm{a}$ & $3.59 \mathrm{a}$ & $(-)$ \\
\hline
\end{tabular}

Keterangan: Angka pada baris dan kolom yang sama diikuti huruf sama menunjukkan tidak berbeda pada tingkat nyata (a) $5 \%$ menurut uji DMRT.(-) tidak terjadi interaksi antar faktor.

\section{Indeks Panen (\%)}

Hasil sidik ragam anova menunjukkan tidak terjadi interaksi antara perlakuan residu kompos biochar yang diperkaya jenis pupuk kandang dan perlakuan umur defoliasi daun jagung pada pengamatan indeks panen. Perlakuan kompos biochar yang diperkaya jenis pupuk kandang dan perlakuan umur defoliasi daun jagung menunjukkan data tidak ada beda nyata antara aras perlakuan (Tabel 13.). Residu dari bahan organik pupuk kandang kambing memberikan dan perlakuan defoliasi daun jagung menghasilkan presentase panen tanaman tertinggi. Hal ini manfaat dari unsur hara yang diserap oleh akar tanaman dan penyerapan cahaya matahari secara langsung kemudian daun tanaman memproduksi hasil asimilat yang tinggi sehingga tanaman mampu meningkatkan presentase panen tanaman kacang.

\begin{tabular}{ccccc} 
Tabel 13. Indeks Panen (\%). & \multicolumn{5}{l}{ Umur Defoliasi (HST) } & Rerata \\
\cline { 2 - 5 } Jenis Residu Kompos & Kontrol & 35 & 75 & \\
Biochar & 60.75 & 53.10 & 55.83 & $56.56 \mathrm{a}$ \\
\hline Pupuk Kandang Sapi & 57.82 & 65.69 & 63.23 & $62.25 \mathrm{a}$ \\
Pupuk Kandang Kambing & 57.31 & 61.08 & 55.76 & $56.71 \mathrm{a}$ \\
\hline Pupuk Kandang Kuda & $53.39 \mathrm{a}$ & $59.96 \mathrm{a}$ & $58.27 \mathrm{a}$ & $(-)$ \\
\hline Rerata & $57.29 \mathrm{a}$
\end{tabular}

Keterangan: Angka pada baris dan kolom yang sama diikuti huruf sama menunjukkan tidak berbeda pada tingkat nyata (a) $5 \%$ menurut uji DMRT.(-) tidak terjadi interaksi antar faktor.

\subsection{Pembahasan}

Tanaman kacang merah dapat tumbuh dan menghasil produksi yang baik bila tumbuh pada lingkungan tumbuh yang optimal. Penelitian membuktikan bahwa kombinasi perlakuan residu kompos yang diperkaya jenis pupuk kandang kuda dan umur tanaman jagung yang diberi defoliasi pada umur 55 HST mampu mengoptimalkan peningkatan suhu tanah pada umur tanaman 60 HST sedangkan pada pengamatan berat volume tanah 60 HST kombinasi perlakuan residu kompos biochar yang diperkaya jenis pupuk kandang sapi dengan perlakuan defoliasi daun jagung pada tanaman berumur 55 HST menghasilkan volume tanah lebih ringan dibandingkan kombinasi perlakuan lain. Hal ini membuktikan bahwa bahan organik yang diaplikasi pada musim tanaman pertama masih mampu mempertahankan kesuburan tanah karena pada umumnya bahan organic bersifat slow release. Pupuk kandang, pupuk kompos dan pupuk hijau merupakan pupuk yang bersifat slow release yakni unsur hara dalam pupuk dilepaskan seara perlahan-lahan dan terus-menerus dalam waktu tertentu sehingga unsur hara tidak segera tersedia bagi tanaman hal ini berdasarkan penelitian Musnawar (2003).

Residu tanaman berfungsi sebagai sumber energi bagi mikroflora Pemberian residu dapat membantu mikrooganisme heterotrop memobilisasi $\mathrm{N}$ selama dikomposisi substrat karbon (Darwis, 1994). Hasil-hasil penelitian menunjukkan bahwa penggunaan pupuk organik seperti pupuk kandang, pupuk hijau dan limbah panen dapat memperbaiki sifat-sifat tanah, disamping mengurangi penggunaan pupuk $\mathrm{N}, \mathrm{P}$ dan $\mathrm{K}$ dan meningkatkan efisiensinya (Karama et al., 1990; Adiningsih, 2000 dan Diwiyanto, 2000). Faktor tungal perlakuan residu kompos biochar yang diperkaya jenis pupuk kandang kambing mampu mempertahankan kelembapan dan menetralkan salinitas tanah. Tas'au (2018) menyatakan bahwa aging Biochar juga meningkatkan kualitas dan kuantitas air dengan meningkatkan retensi tanah, nutrisi dan bahan kimia pertanian untuk pemanfaatan tumbuhan dan tanaman. Selanjutnya penelitian Hartun (2019), pada awal penanaman pada lokasi yang sama membuktikan bahwa perlakuan kompos biochar yang diperkaya jenis pupuk kandang kambing mampu mengoptimalkan suhu tanah, dan menetralkan salinitas tanah Faktor tungal perlakuan defoliasi daun jagung pada umur 55 hst mampu mempertahan peningkatan suhu tanah dan menjaga kelembapan tanah serta membuat tekstur tanah menjadi lebih ringan. Jumin (2002) dalam Marliah et al. (2010) menyatakan bahwa tujuan dari sistem tanam tumpang sari adalah untuk mengoptimalkan penggunaan hara, air, dan sinar matahari seefisien mungkin untuk mendapatkan produksi maksimum.

Lingkungan yang optimal mampu meningkatkan pertumbuhan tanaman. Perlakuan residu kompos biochar yang diperkaya jenis pupuk kandang kuda mampu meningkatkan pertumbuhan tanaman. Terbukti dalam pengamatan tinggi tanaman pada setiap pengamatan, menghasilkan jumlah daun terbanyak, dan bintil akar efektif terbanyak. Perlakuan residu kompos biochar yang diperkaya jenis pupuk kandang kambing menghasilkan luas daun tanaman terbesar. Laus daun yang besar mungkin diakibatkan oleh kandungan unsur hara nitrogen yang tersisa didalam tanah masih banyak. Hal ini sejalan dengan hasil penelitian Trivana et al., (2017) bahwa kompos kotoran kambing memiliki kandungan nitrogen antara 2,23-2,24 \% pada waktu pengomposan 10-20 hari. Selain itu dikatakan bahwa residu dari bahan organik yang terkandung dalam tanah masih efektif untuk dimamfaatkan tanaman dalam meningkatkan pertumbuhan tanaman. Menurut Poerwowidodo (1992) bahwa bahan organik mampu melapisi jarak tanah, sehingga mengurangi loka penambatan dan reaksinya dengan liat. Pertumbuhan tanaman dapat diartikan pembelahan sel (peningkatan jumlah) dan pembesaran sel (peningkatan ukuran) dan merupakan proses yang tak dapat balik (Gardner et al., 1985). Sedangkan faktor tunggal perlakuan umur defoliasi daun jagung 55 HST mampu meningkatkan pertumbuhan tanaman kacang merah dengan bentuk karakter, tinggi tanaman tertinggi, jumlah daun tanaman paling banyak, bintil akar efektif paling banyak. Biamnasi, (2019), membuktikan dalam penelitiannya bahwa pertumbuhan tanaman yang diamati pada tanaman jagung menunjukkan parameter pertumbuhan terbaik yaitu tinggi tanaman dan jumlah daun 21 dan 42 HST efek dari penggunaan biochar dan tanaman jagung yang ditumpangsarikan dengan jenis kacang (Vigna Umbellata L.).

Pertumbuhan tanaman yang baik mampu meningkatkan hasil tanaman, penelitian membuktikn bahwa terjadi pengaruh positif antara kombinasi perlakuan residu kompos biochar diperkaya pupuk kandang sapi dengan perlakuan umur defoliasi daun jagung 35 HST pada pengamatan berat tajuk. Faktor tunggal perlakuan residu kompos biochar diperkaya jenis pupuk kandang kambing mampu meningkatkan hasil tanaman, yang dieskpresikan dengan panjang polong tertinggi, berat biji per petak terberat, berat 100 biji terberat, berat biji per Ha, dan menghasilkan presentase panen tertinggi. Residu Biochar pada musim tanam ketiga menghasilkan nilai lebih tinggi terhadap 
serapan $\mathrm{N}$ tanaman, serapan $\mathrm{K}$ tanaman, jumlah daun, bobot basah berangkasan, bobot kering berangkasan namun, tidak lebih tinggi pada tinggi tanaman. Biochar takaran $5 \%$ meningkatkan serapan $\mathrm{K}, \mathrm{pH}$ tanah, jumlah daun, dan bobot kering berangkasan (Harryadi, 2016).

Menurut Hakim etal., (1986) bahwa pupuk organik mempunyai efek residu yang haranya secara berangsur menjadi bebas dan tersedia bagi tanaman pengaruhnya berlangsung hingga 3 sampai 4 tahun setelah proses aplikasi seperti unsur N,P dan K diserap oleh akar tanaman dan diangkut ke daun untuk diasimilasikan pada reaksi fotosintesis. Hal ini membuktikan bahwa residu bahan organik mampu memperbaiki sifat fisik, biologi, dan kimia tanah sehingga tanaman memanfaatkannya dengan meningkatkan hasil tanaman. Residu biochar diperkaya amonium sulfat mempengaruhi tinggi tanaman, anakan produktif, berat kering brangkasan, berat kering gabah dimana biochar diperkaya amonium sulfat memiliki nilai tertinggi berturut-turut $106,17 \mathrm{~cm}$; 6,22 anakan polibag ${ }^{-1} ; 69,33 \mathrm{~g} ; 12,74 \mathrm{~g} ; 17,89 \mathrm{~g} ; 9,40 \mathrm{~g}$. Tekstur tanah mempengaruhi jumlah malai pada tekstur liat dengan nilai 6,89. Safuan et al. (2012) menambahkan bahwa residu pemberian bahan organik 15 ton memberikan pengaruh yang lebih baik terhadap pertambahan luas daun, jumlah daun, tinggi tanaman, diameter batang, panjang polong, jumlah polong pertanaman, berat polong segar pertanaman dan meningkatkan produksi tanaman. Biamnasi, (2019) menyatakan bahwa biochar ke dalam tanah menyebabkan beberapa parameter pertumbuhan dan hasil tanaman lebih rendah dari kontrol seperti tinggi tanaman, jumlah daun, berat 100 biji, berat biji per petak, dan indeks panen.

Perlakuan umur defoliasi daun jagung pada umur 55 HST mampu meningkatkan hasil tanaman, hal ini dibuktikan bahwa tanaman legum membutuhkan naungan yang untuk meningkatkan hasil tanaman. Metkono (2019) menyatakan bahwa umur defoliasi daun jagung pada umur 35 HST memberikan hasil panjang tongkol terpanjang, diameter tongkol terbesar,jumlah biji perbaris terbanyak, berat biji pertanaman terberat, berat 100 biji terberat, berat biji perpetak terberat dan berat biji per hektar terberat dibandingkan dengan tanpa defoliasi dan defoliasi 75 HST. Sedang penelitian Biamnasi, (2019) menunjukkan bahwa tanaman jagung yang ditumpangsarikan dengan jenis kacang (Vigna umbellata L.) memberikan hasil yang terbaik yang dapat diekspresikan dalam bentuk berat biji pertanaman terberat, berat 100 biji terberat, berat biji perpetak terberat, berat biji/ha terberat dan berat brangkasan terberat. Menurut Surtinah (2005) bahwa pemangkasan seluruh bagian daun tanaman pada saat pengisian biji menyebabkan bagian tanaman diatas tongkol tidak memperoleh hasil fotosintesis. Selain itu pengguratan seluruh helaian daun menyebabkan hilangnya organel-organel penting fotosintesis, sepert klorofil dan stomata, sehingga penumpukan hasil asimilasi pada biji berasal dari hasil respirasi atau dari organ tanaman yang bukan daun. Hal ini sesuai dengan pernyataan Surtinah (2005) tiga sumber utama asimilat yang digunakan untuk pengisian biji yaitu fotosintesis daun saat sekarang, fotosintesis bagian lain yang bukan daun saat sekarang, dan remobilisasi hasil asimilasi yang disimpan dalam organ tanaman yang lain.

\section{Simpulan}

Berdasarkan hasil penelitian menunjukkan bahwa terjadi interaksi antara perlakuan jenis residu kompos biochar dan perlakuan umur defoliasi daun jagung terhadap suhu tanah 60 HST, dan berat volume tanah 60 HST.Faktor tunggal perlakuan jenis residu kompos biochar yang diperkaya pupuk kandang kambing mampu memodifikasi lingkungan tumbuh tanaman dan meningkatkan pertumbuhan serta meningkatkan hasil tanaman.Faktor tunggal perlakuan umur defoliasi daun jagung 35 HST memberikan performa pertumbuhan kacang merah terbaik.

\section{Pustaka}

Adie, M.M., Agung D. K. 2002. Kacang Merah dan Peluang Pengembangannya di Indonesia. Puslitbang Tanaman Pangan. Balitbang Pertanian. Jakarta: 111.

Adiningsih, J. S. 2000 Peranana Bahan Organik Tanah dala Sistem Usaha Tanah dalam Sistem Usaha Tani Konservasi. Makala di sampaikan sebagai bahan pelatihan revitalisasi keterpaduan ternak dalam sistem usaha tani, di Bogor dan Solo, 21 Februari-6 Maret 2000.

Biamnasi, Y. 2019. Efek Takaran Biochar Dan Jenis Kacang Terhadap Pertumbuhan Dan Hasil Kacang Dalam Sistem Tumpangsari Salome Dengan Jagung Pada Lahan Kering. Skripsi Fakultas Pertanian Universitas Timor.

Butt, M. S., dan Batool, R. (2010). Nutritional and functional properties of some promising legumes protein isolates.

BOA. 2008. Pertanian Organik Penyelamat Ibu Pertiwi. Denpasar. Bali Organic

Darwis, 1994. Pemanfaatan Residu Tanaman Dalam Upaya Mengurangi Pencemaran Nitrat Pada Daerah Pertanian Intesif. Kendari.

Data BPS Kabupaten Timor Tengah Utara. 2011. Timor Tengah Utara Dalam Angka. Kefamenanu.

Diwiyanto, K. 2000. Restrukturisasi Peta Kesesuaian dan Pemberdayaan Sumber Daya Unggulan (Pembangunan Pertanian-peternakan di Indonesia) .Makala disampaikan sebagai bahan pelatihan revitalisasi keterpaduan ternak dalam sistem usaha tani, di Bogor dan Solo, 21 Februari - 6 Maret 2000.

Gardner, Susilo, H. dan Subiyanto. 1985. Fisiologi Tanaman Budidaya. (Penerjamah). UI Press: Jakarta.
Gomez, K.A., Gomez, A.A. 2010. Prosedur Statistik Untuk Penelitian Pertanian. Edisi ke 2. UI Press: Jakarta.

Hartun, 2019. pengaruh waktu defoliasi daun jagung (zea mays l) dan kompos biochar diperkaya jenis pupuk kandang pada lahan inseptisol terhadap perumbuhan dan hasil kacang hijau (vigna radiata l) dalam tumpangsari salome . Skripsi Fakultas Pertanian Universitas Timor.

Hakim, N., Nyakpa, M. Y., Lubis, A.M., Nugroho, S.G., Saul, M.R., Dine, M.A., Hong. G.B., dan Bailey, H.H., 1986. Dasar-dasar ilmu tanah. Universitas Lampung. Bandar Lampung. 488 hal.

Harryadi, A. 2016. Pengaruh residu biochar terhadap pertumbuhan dan serapan $N$ dan $K$ tanaman kedelai (Glycine max L.) pada topsoil dan subsoil tanah ultisol. Skripsi. Program studi Agroteknologi. Fakultas pertanian Universitas lampung. Lampung.

Herman. 2002. Aplikasi Bahan Organik serta waktu perompesan daun bawah tongkol terhadap pertumbuhan dan produksi tanaman jagung (zea mays L.) program pasca sarjana universitas hasanuddin makassar.

Hopkins. 1995. Introduction to Plant Physiology. John Willey and Sons Inc, Singapore.

Islami (2012). Pengaruh residu bahan organik pada tanaman jagung sebagai tanamansela pertanaman ubi kayu. Buana Sains. Vol. 12. 1.

Jumin, H. B. 2002 Agronomi PT. Raja Grafindo persada, Jakarta

Karama, A.S marsuki, A.R., manwar, i.1990, penggunaan pupuk organik pada tanaman pangan. Prosiding lokakarya nasional efisiensi pupuk v; cisarua, 12-13 november 1990, bogor: pusat penelitian tanah. 395-425 hal.

Lehman, J. and M. Rondon. 2006. Bio-car Soil Management oon HighlyWeatherred Soil in The Humid Tropics. In: N. Uphoff (ed.), Biological Approaches to Susttainable Soil Systems, Boca Rston, CRC Press. Taylor and Francis Group. P. 517 - 530.

Levis L. R., K. Sukesi, Sugiyanto and Y. Yuliati., 2017. Farmers BehaviourRegarding Food Security by Practicing The „Salome" Farming Systemas Local Wisdom in West Timor, East Nusa Tenggara Province,Indonesia. Tropical and Subtropical Agroecosystems, 20 (2017): 231 - 236. Diakses 21 Februari 2018.

Marliah, A., Jumini, Jamilah, 2010. Pengaruh jarak tanam antara baris pada sistem tumpangsari beberapa varietas jagung dengan kacang merah terhadap pertumbuhan dan hasil. J.Agrista vol. 14 (1):30-38.

Metkono, V. 2019. Efek Takaran Biocha rDan Umur Defoliasi Daun Jagung Terhadap Pertumbuhan Dan Hasil Jagung Dalam Sistem Tumpangsari Salome Dengan Kacang Pada Lahan Kering. Skripsi Fakultas Pertanian Universitas Timor.

Musnawar, E 2003. Pupuk Organik. PT. Penebar Swadaya, Bogor.

Nurfi, A. 2009. Kacang Merah Turunkan Kolesterol dan Gula Darah. Jakarta: Depkes RI.

Naben. (2017). Pengaruh takaran pupuk guano dan biochar terhadap pertumbuhan dan hasil tanaman kacamg merah (Phaseoulus vulgaris L) di dataran menegah.

Permanasari, I. dan D. Kastono. 2012. Pertumbuhan Tumpang saari Jagung daan Kedelai padaa Perbedaan waktu Tanam dan Pemangkasan Jagung. Jurnal Agrotenogi. 3(1): 13 - 20.

Poerwowidodo, 1992. Telaah Kesuburan Tanah, Penerbit Angkasa Persada Jl. Kronolodong No. 37, Cetakan keempat Bandung.

Trivana Linda, Adhitya Yudha Pradhana, Alfred Pahala Manambangtua, 2017, Optimalisasi Waktu Pengomposan Pupuk Kandang Dari Kotoran Kambing Dan Debu Sabut Kelapa Dengan Bioaktivator EM4, Jurnal Sains dan Teknologi Lingkungan, Volume 9, Nomor 1

Safuan, La Ode dan Andi Bahrun. 2012. Pengaruh Bahan Organik dan Pupuk Kalium Terhadap Pertumbuhan dan Produksi Tanaman Melon (Cucumis melo L). Jurnal Agroneknos Juli 2012. Vol. 2. No. 2. Hal. 69-76. ISSN: 2087-7706.

Setyati, 1979. Masalah Produksi Lombok. Departemen Agronomi,Fakultas Pertanian, IPB. Bogor. Hal, 66

Setyamidjaja, D.1986. Pupuk dan Pemupukan. CV. Simplex. Jakarta.

Sukoco, Y., C. Reintjes, Haverkort, B. Dan dan Woter, 1992. Pertanian masa depan. Kanisius. Yogyakarta.

Surtinah.,2005 Hubungan Pemangkasan Organ Bagian Atas Tanaman Jagung (Zea mays L.) dan Dosis Urea Terhadap Pengisian Biji. Jurnal Ilmiah Pertanian Vol.1 no 2 Februari 2005.

Tas'au, F. 2018. Kajian Residu Pupuk Guano Dan Aging Biochar Terhadap Pertumbuhan Dan Hasil Kacang Merah (Phaseolus Vulgaris L.) Di Dataran Menengah Pada Musim Tanam 2. Skripsi Fakultas Pertanian Universitas Timor.

Tambunan, S., Bambang, S., dan Eko, H. 2014 Pengaruh Aplikasi Bahan Organik Segar Dan Biochar Terhadap Ketersediaan P Dalam Tanah Di Lahan Kering Malang Selatan. Universitas Brawijaya. Jurnal Tanah Dan Sumberdaya Lahan Vol.1 No 1: Hal 85-92

Yulia, A.E. dan Murniati. 2010. Aplikasi Pupuk Organik Pada Tanaman Caisim Untuk Dua Kali Penanaman. Jurnal Teknobiologi 1(2): 19 - 26. 